PALEO

Revue d'archéologie préhistorique

26 | 2015

Varia

\title{
Something new in Combarelles I (Les Eyzies-de- Tayac, Dordogne, France)
}

Du nouveau aux Combarelles I (Les Eyzies-de-Tayac, Dordogne, France)

Elena Man-Estier, Emeline Deneuve, Patrick Paillet, Lucie Loiseau and Catherine Cretin

\section{(2) OpenEdition}

1 Journals

Electronic version

URL: http://journals.openedition.org/paleo/3032

DOI: $10.4000 /$ paleo.3032

ISSN: $2101-0420$

Publisher

SAMRA

Printed version

Date of publication: 1 December 2015

Number of pages: $201-214$

ISSN: $1145-3370$

\section{Electronic reference}

Elena Man-Estier, Emeline Deneuve, Patrick Paillet, Lucie Loiseau and Catherine Cretin, « Something new in Combarelles I (Les Eyzies-de-Tayac, Dordogne, France) », PALEO [Online], 26 | 2015, Online since 26 April 2016, connection on 07 July 2020. URL : http://journals.openedition.org/paleo/3032 ; DOI https://doi.org/10.4000/paleo.3032

This text was automatically generated on 7 July 2020 .

\section{cc) (ㅇ) $\ominus$}

PALEO est mis à disposition selon les termes de la licence Creative Commons Attribution - Pas d'Utilisation Commerciale - Pas de Modification 4.0 International 


\section{Something new in Combarelles I (Les Eyzies-de-Tayac, Dordogne, France)}

Du nouveau aux Combarelles I (Les Eyzies-de-Tayac, Dordogne, France)

Elena Man-Estier, Emeline Deneuve, Patrick Paillet, Lucie Loiseau and Catherine Cretin

The authors are thanking Jean-Jacques Cleyet-Merle and George Levy as well as the team of guides (National Monuments Centre) for allowing and facilitating access to the cave, Genevieve Pinçon (Prehistory National Centre) for making possible the Master thesis of Lucie Loiseau and John Hartmann for his permission to use the DStretch@ software. This operation is financed by the Ministry of Culture and Communication, Sub-Directorate of Archaeology - DRAC Aquitaine.

\section{Combarelles I, discovery and context}

1 The cave of Combarelles I opens up on the left bank of the Beune River, a tributary of the Vézère, at the end of a small valley. It is located three kilometres upstream from the village of Les Eyzies-de-Tayac and a few hundred meters away from the cave of Font de Gaume (fig. 1). The entrance, consisting of a large porch, gives access to two independent decorated galleries, Combarelles I and Combarelles II (Aujoulat 1984; Barrière 1984; Roussot 1976).

2 At the end of Combarelles I, a third decorated area (Combarelles III) was discovered in 2005 by Marc Delluc (Cleyet-Merle, Feruglio, Delluc in press). Combarelles I cave is dug in the same Coniacian limestone as several other caves in the region but its morphology is slightly different. It is rather long $(249 \mathrm{~m})$ just for the fossil network, and appears as a single "zigzag"-shaped winding corridor (Barrière 1997) (fig. 2). The gallery is modest in width (between 0.60 and $1.50 \mathrm{~m}$ ). In the Palaeolithic, it was between 0.5 and $1.5 \mathrm{~m}$ high, up to $2 \mathrm{~m}$ locally. In 1911, ten years after the discovery, the floor was lowered by over $0.50 \mathrm{~m}$ to facilitate visitors 'access. The supporting bedrock, light beige in colour, 
has been covered regularly by a coating of calcite varying in appearance from white opaque to translucent grey depending on humidity and outdoor weather conditions. In the last part of the gallery, the walls are covered with decalcification clay, sometimes cut into by engravings and partially covered with calcite.

The cave of Combarelles I is part of the very first decorated sites recognized in the Vézère Valley in the early twentieth century. This is even the first cave "invented" jointly by Louis Capitan, Henri Breuil and Denis Peyrony, the future "decorated cave trust" (Hurel 2011). It convinced the scientific community of the existence and old age of Palaeolithic art. The cave was discovered on September 8, 1901 and reported to the Academy of Sciences on September 18 (fig. 3) (Capitan and Breuil 1901; Cleyet-Merle 1990). The first publications (Capitan and Breuil 1902a, 1902b and 1902c) reported one hundred representations. Some notable engravings were highlighted such as 14 mammoths that constituted a strong evidence in favour of the Palaeolithic age of the site. The study conducted subsequently by H. Breuil completed the corpus (Capitan, Breuil, Peyrony 1924).

From 1978, a new study was conducted by Claude Barrière. His tracings were published in several volumes of the "Travaux de l'Institut d'Art préhistorique de Toulouse" (Barrière 1980, 1981, 1983a, b, 1985 and 1987). A commented volume, completed with a synthesis, was published in a special issue of the Paléo journal (Barrière 1997). From 1980, Monique and Claude Archambeau conducted new readings and published new graphical entities (Archambeau M. 1984; Archambeau M. and C. 1986, 1991).

5 The archaeological context of the site is poorly known. As early as 1892, the porch and the galleries were excavated by Emile Rivière (Rivière 1894). The scarce material collected confirms Upper Palaeolithic visits. In 1973, a rescue excavation was conducted by Jean-Philippe Rigaud (1984). It showed the remains of two settlement levels, dated respectively between 13,698 and 12,784 years cal BP for the upper level, and 17,174 and 15,939 years cal BP for the lower level ${ }^{1}$.

6 Relaying on the style of the representations and the presence of some thematic markers (tectiforms signs, schematic female figures), authors have proposed a date between the Middle Magdalenian and the Upper Magdalenian, this is to say around $15,000 \mathrm{BP}$ non cal, for the decoration. 
Figure 1 - Localisation of the cave of Combarelles. Drawing E. Deneuve after Barrière 1997.

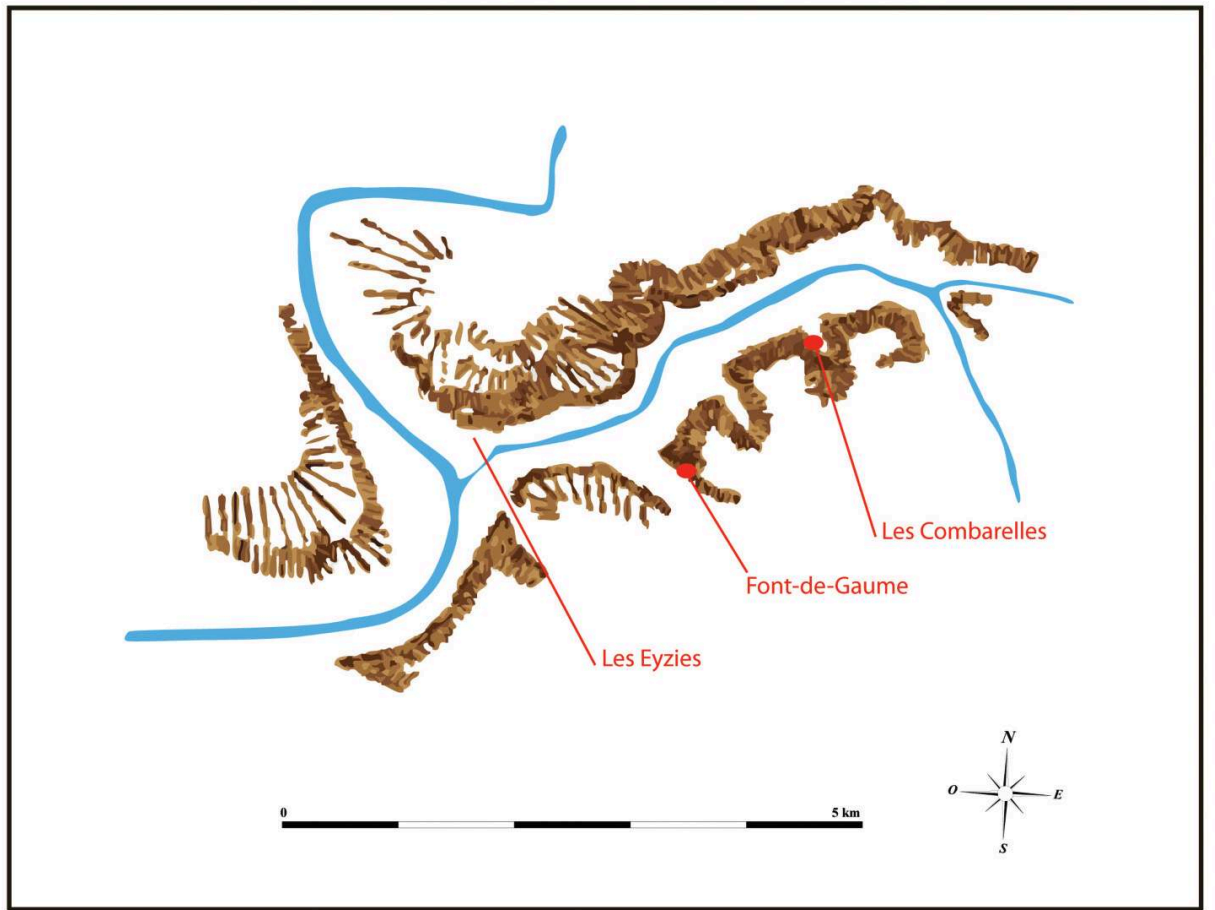

Figure 2 - Map of Les Combarelles I. Drawing E. Deneuve after Barrière 1997.

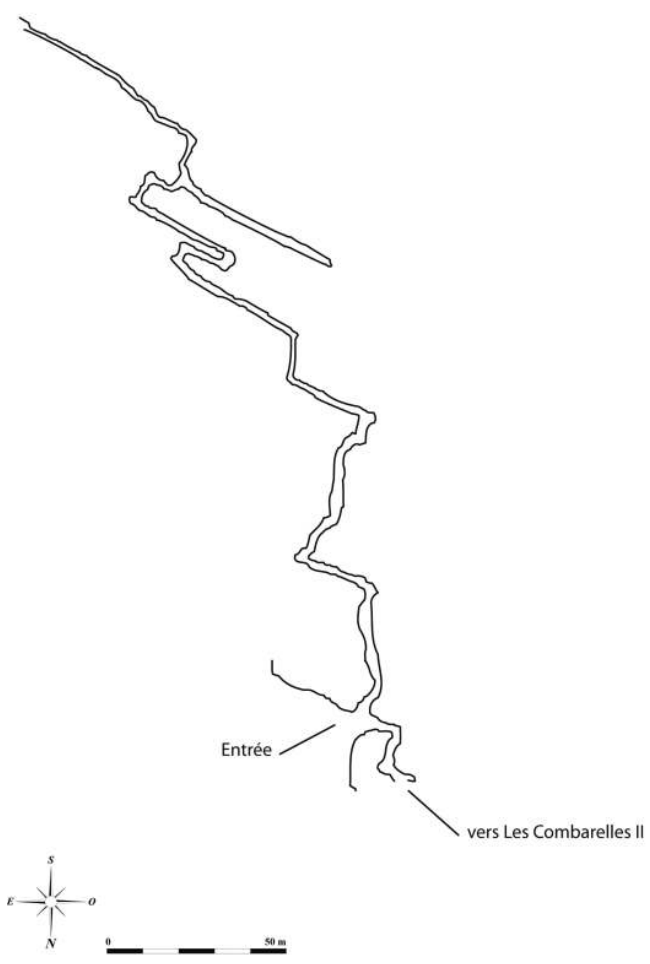


Figure 3 - Letter written by Dr Capitan explaining the discovery of Les Combarelles I, In: CleyetMerle 1990.

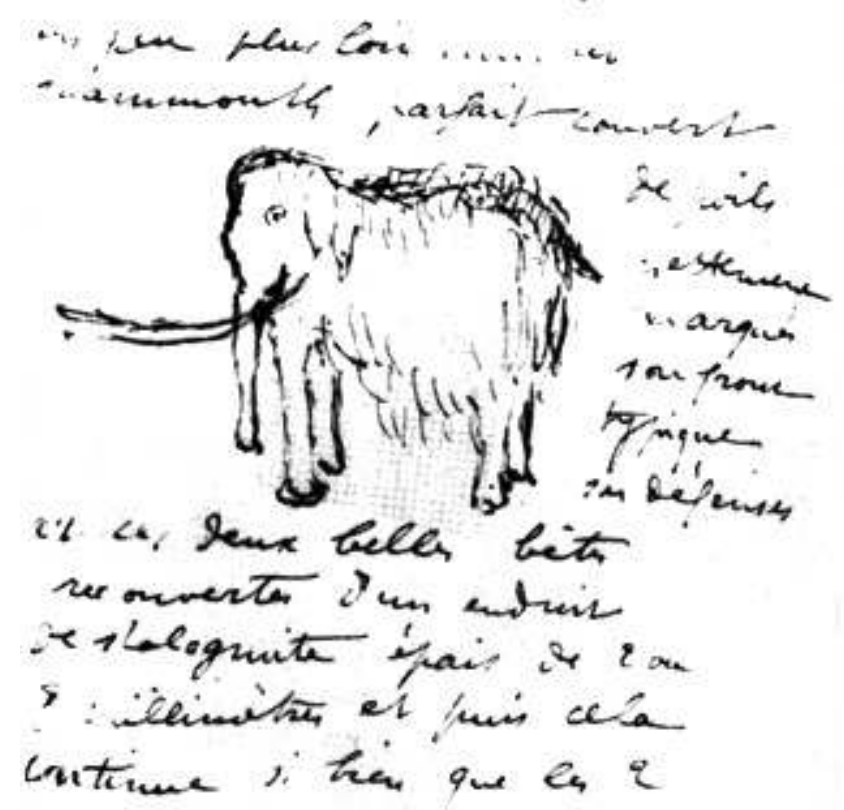

\section{The decorated corpus of Combarelles I: engravings and paintings}

7 The main originality of the art of Combarelles I is the entanglement of the engravings (fig. 4). The decoration is present from the first tens of meters of the network but it is mostly concentrated in the last 100 meters of the gallery. The assemblage is characterized by a high density and an iconographic continuity rarely interrupted by uneven wall reliefs or by the bends along the path.

8 The overall inventory published by H. Breuil (Capitan, Breuil, Peyrony 1924) mentioned nearly 300 engraved representations. In 1902, L. Capitan and H. Breuil reported that "on some figures, the engraved lines are enhanced by a narrow strip of black paint that sometimes replaces them" (Breuil and Capitan 1902). In 1924, about thirty "drawings" were listed.

Out of these, 16 figurative representations were individualized and sometimes identified (horses, ibex and signs in particular). Claude Barrière doubled this general corpus while rejecting some of the previously published figures. His inventory (1997) includes 625 units distributed as 529 engravings and 96 drawings. The "figures", overwhelmingly animals (Barrière 1997 - p. 474), are 460. The inventory of figurative drawings (16) is equivalent to H. Breuil's (fig. 5).

As part of a new archaeological operation, we had the opportunity to conduct a new reading of the drawings ${ }^{2}$ and to complete $C$. Barrière's inventory. A detailed re-reading of the rock walls allowed to individualize thirty additional painted patterns, taking the corpus to 121 graphics units. They are for most non-determinable and much faded entities: stains, dots or discontinuous tracing sections (fig. 6).

11 If we consider all the representations in Combarelles I, the corpus is largely dominated by the Horse. Claude Barrière identifies 141 of them, that is to say nearly a third of the 
figurative inventory and over $20 \%$ of all graphical entities. Within the painted corpus, horses also figure prominently (9 out of 16 figurations).

Humans make the second theme $(n=55)$. The shapes of representation are varied: complete human, parts (genitalia, hands), bestialized heads and schematic female figures. Monique and Claude Archambeau (1991) classify these humans into four groups (expressive, enigmatic, geometrical and undetermined human figures). The remainder of the figurative inventory is fairly standard. C. Barrière's inventories (1997) reported 42 bovines, among which 38 bison, 24 mammoths and 21 deer. Finally, the presence of species that are rarer in the Magdalenian bestiary can be noted, like the bear $(n=9)$ (Man- Estier 2009), the lion ( $n=3)$, the canids $(n=3)$, the hyena $(n=1)$ and one mustelid. Finally, the corpus of abstract signs is of 69 graphic entities.

Figure 4 - Engraving panel of Les Combarelles I, tracing H. Breuil.

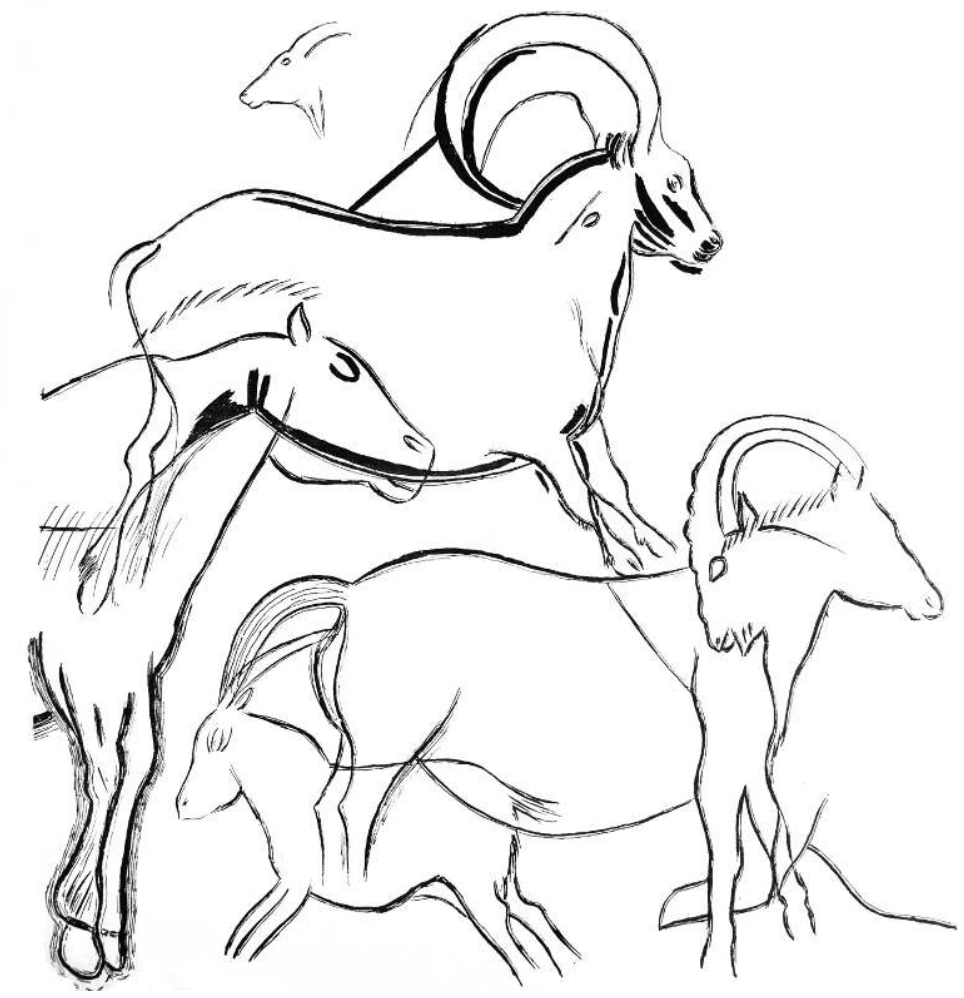


Figure 5 - Black drawings in Les Combarelles I, picture Ph. Jugie (๑ CMN).

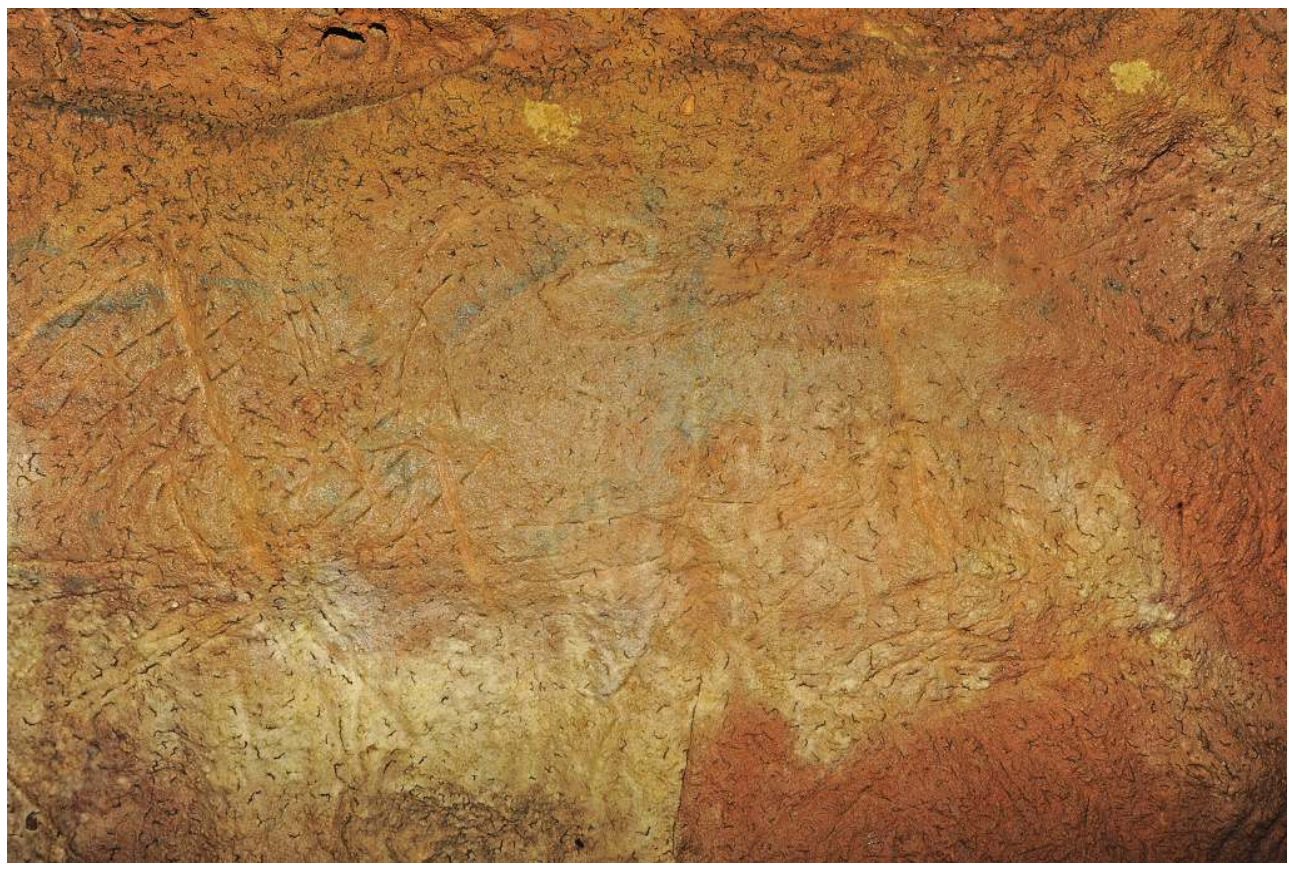

Figure 6 - New black pattern in Les Combarelles I. Improved D-Strech treatment. Picture P. Paillet, treatment $\mathrm{E}$. Man-Estier.

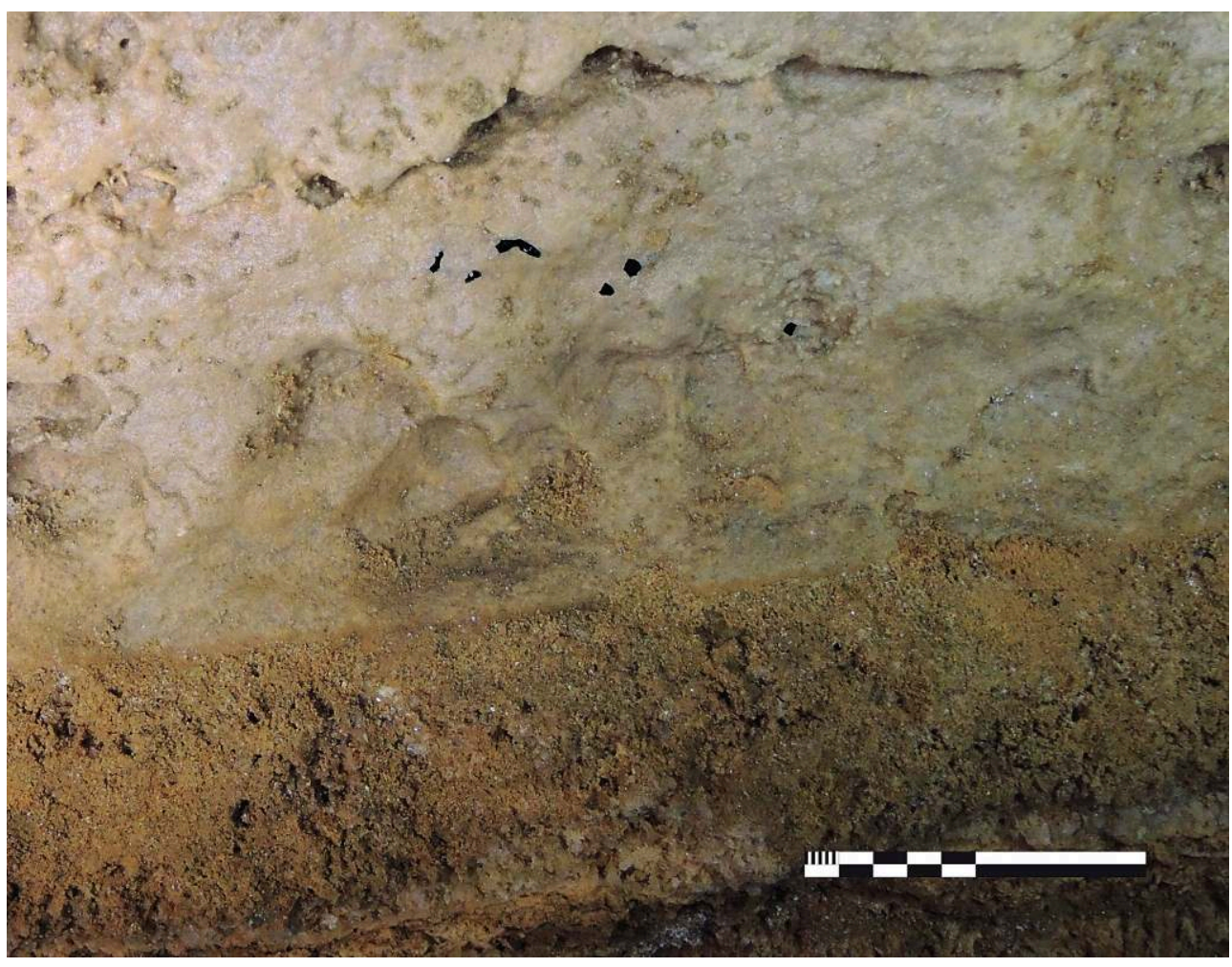




\section{New problematic and new tools}

13 The cave has undergone numerous natural alterations that have damaged the walls with varying intensity. Coatings of whitish calcite have occurred during humid periods and are still occurring today. Barely visible under the layer of calcite, the drawings seem to have lost much of their interest for the past researchers " 5 drawings, this is not much" (Barrière 1997 - p. 514).

Thus, except for a few tracings that remain identifiable, they have been perceived as anecdotal, limited and without connection with the engraved corpus. Claude Barrière has chosen to publish them apart from the engravings, carrying out two series of different tracings.

But to take the full measure of the decorated system, it seems essential to us to associate drawings and engravings. Our new study ${ }^{3}$ was proposed in this light. The first results are presented below.

Our analysis is based on an inventory drawn from systematic surveying of the rock walls and from a photographic and graphic double recording of the identified figures. In parallel, digital image processing is applied to the representations to improve the readability of the lines. We used the D-Stretch $\odot$ plugin from the ImageJ $\odot$ software (Hartmann 2011). Its use is now widespread in the scientific community especially for the study of rock art. Several authors have extensively developed its interest before us (Brady et al. 2012; Defrasne 2014; Hollmann and Crause 2011; Quellec et al. 2013; Quellec, Duquesnoy, Defrasne 2015).

17 It is true that this free tool, regularly updated, offers a rather simple user interface for often dramatic results. We systematized the use of this software by inserting it in our analysis of the Combarelles I corpus, after the first stage of exploration and inventory on the rock wall. A second post-production stage on the computer further improved the result obtained by D-Strech $\odot$ and allowed overlaying it onto the original photograph. The digital processing result is spectacular as it helps to make visible what is almost invisible today. This is, however, only a computer process, which is in no way intended to replace in situ observation and tracings.

\section{An updated corpus}

In 2014, we identified 121 coloured graphics entities. We focused on the middle and deep parts of the cave (sectors VI to X after C. Barrière), characterized as early as 1901 as the main decorated areas. Of these, 31 are new entities. Three others were evoked by C. Barrière (1997) but did not figure in his publications.

We considered as a "graphic unit" any pattern inscribed into a space defined by gaps in the decoration or uneven reliefs. Some figures seem homogeneous from a technical or thematic point of view, but are part of a larger space, up to several meters. They are recorded as overall graphics unit, subdivided if necessary to facilitate their description. Particular attention was paid to the vocabulary used to describe the expression techniques used. Our definitions are based on those proposed in the book written by the Reflection Group on Palaeolithic parietal Art (Collective, 1993) and in the Dictionary of Prehistory (Vialou ed. 2004). We have distinguished stains, dots or lines, from flat tints. The differences between drawings and paintings fall under the specific methods 
of preparation and application of the pigment that are unknown to us at this stage of the study.

The majority of the identified elements is black $(n=110)$. The pigment was sometimes thrown onto the wall $(n=24)$. Line painting is most common $(n=51)$. Several delimited marks $(n=45)$ evoke dabbing (fig. 7). The chronology of the making of the tracings is often difficult to establish. However, out of a dozen of figures that combine painting and engraving, we could make some observations that contradict previous hypotheses. Indeed, while $\mathrm{H}$. Breuil did not detail the chronological sequences, C. Barrière said that "all the coloured traces predate the engravings" (Barrière 1983 - p. 69). In fact, this is by no means a permanent feature. On the contrary, several figures have a complex chronology that allows us to suggest that the engravings and the paintings are contemporary.

Red graphics units are few $(\mathrm{n}=11)$ and mainly limited to stains or punctuations. However, several more constructed groups, which can be described as signs, are drawn or painted in red. This is the case of the two larger signs of the parietal set up, a partitioned rectangle juxtaposed with the VIIIG104 lioness and an elaborate pattern considered a "pseudo-tectiform" at the end of the set up (XDD42). We generally observed more red elements on the left wall than on the right one, with a higher concentration in the sector VII, between 176 and 181 meters from the entrance.

Out of the 121 drawings identified, 32 are figurative representations. This total includes paintings that are in themselves a figurative pattern (mostly animal) or that fit within an engraved figure, presenting a thematic link with it (fig. 8). Horses are the most frequent (14 certain figures and 10 likely). The other themes are reindeer $(n=4)$, felines $(\mathrm{n}=2)$, mammoth $(\mathrm{n}=1)$ and ibex $(\mathrm{n}=1)$ (fig.9).

Three abstract patterns show a complex construction. The first one, drawn in black, is associated to an engraved bison (fig. 10). The other two are red, without connection with the engravings (fig. 11). There is also a hand stencil located at the entrance of the terminal part of the cave. It is partly found in a concavity in the vault (fig. 12).

Most of the corpus consists of indeterminate lines $(\mathrm{n}=87)$. They are isolated lines, stains or coloured tints. Three tracings are likely animal segments (head and spine).

The thematic links between engravings and drawings are an important subject for reflection. Regarding the horse, we noted 22 cases of superimposition. They are most often partial pattern, placed on specific locations on the body of the animal: contour lines or anatomical points such as the shoulder or the groin. In addition, 35 engraved horses are associated with coloured markings without us being able to highlight an anatomical connection. Finally, two horses seem exclusively drawn (fig. 13).

Regarding the other themes, a drawn mammoth comes in perfect complement to an engraved one. Six engraved mammoths are associated with coloured markings. Three reindeer show a combination of engraving and colour. Two others bear colour remains for which we cannot specify whether they are really anatomical elements. One reindeer is only drawn, unrelated to the surrounding engravings. The two engraved lions have black stains: an eye for the "lioness", two dots on the body for the lion in front of it. Coloured markings are superimposed on three engraved bison, but there is no painted bison. An ibex shows a careful combination between engraving and line painting (fig. 4 and fig. 9). Finally, the drawing of a non-determinable animal unconnected with an 
engraved figure and an indeterminate engraved animal bearing colour remains complement these observations.

Engraved human figures and coloured marks are associated on five panels of the cave. Note also the red dots on the anthropomorphs in the "conch" between sectors VI and VII.

The study of the location of the drawn graphical entities allows to highlight a real continuity in the use of pigments, which are not kept for a specific part of the cave. Sector X, however, is the densest (49 graphic units). This could correspond to a differential conservation problem in this area, which is far from the entrance and closed to visitors.

The left and right walls bear colour in a roughly equivalent proportion. We identified a total of 62 graphic entities on the left wall and 59 on the right wall. Some elements were also spotted on the ceiling. They are essentially stains, although some patterns seem more organized.

Figure 7 - Several drawing techniques enlighted with digital treatment. Up, line made of ponctuation, down, painted line. D-Strech treatment. Picture P. Paillet.
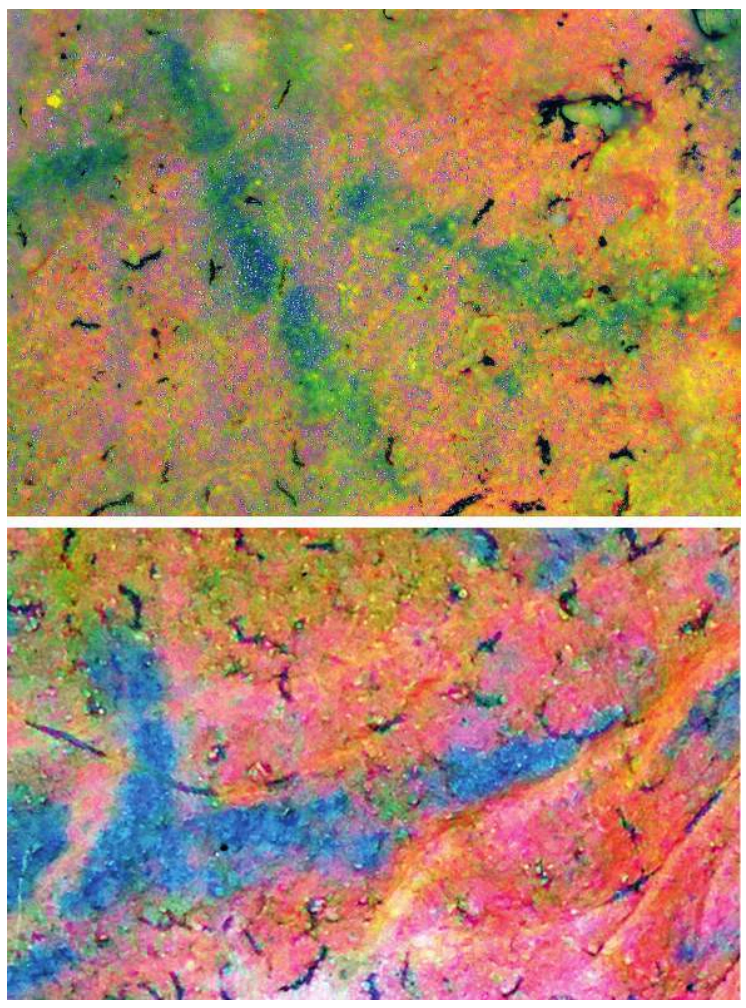
Figure 8 - Example of thematic relation. Head of horse VID47 (C. Barriere) that has been superposed with drawn horse Cb32. Improved D-Strech treatment. Picture P. Paillet, treatment E. Man-Estier.

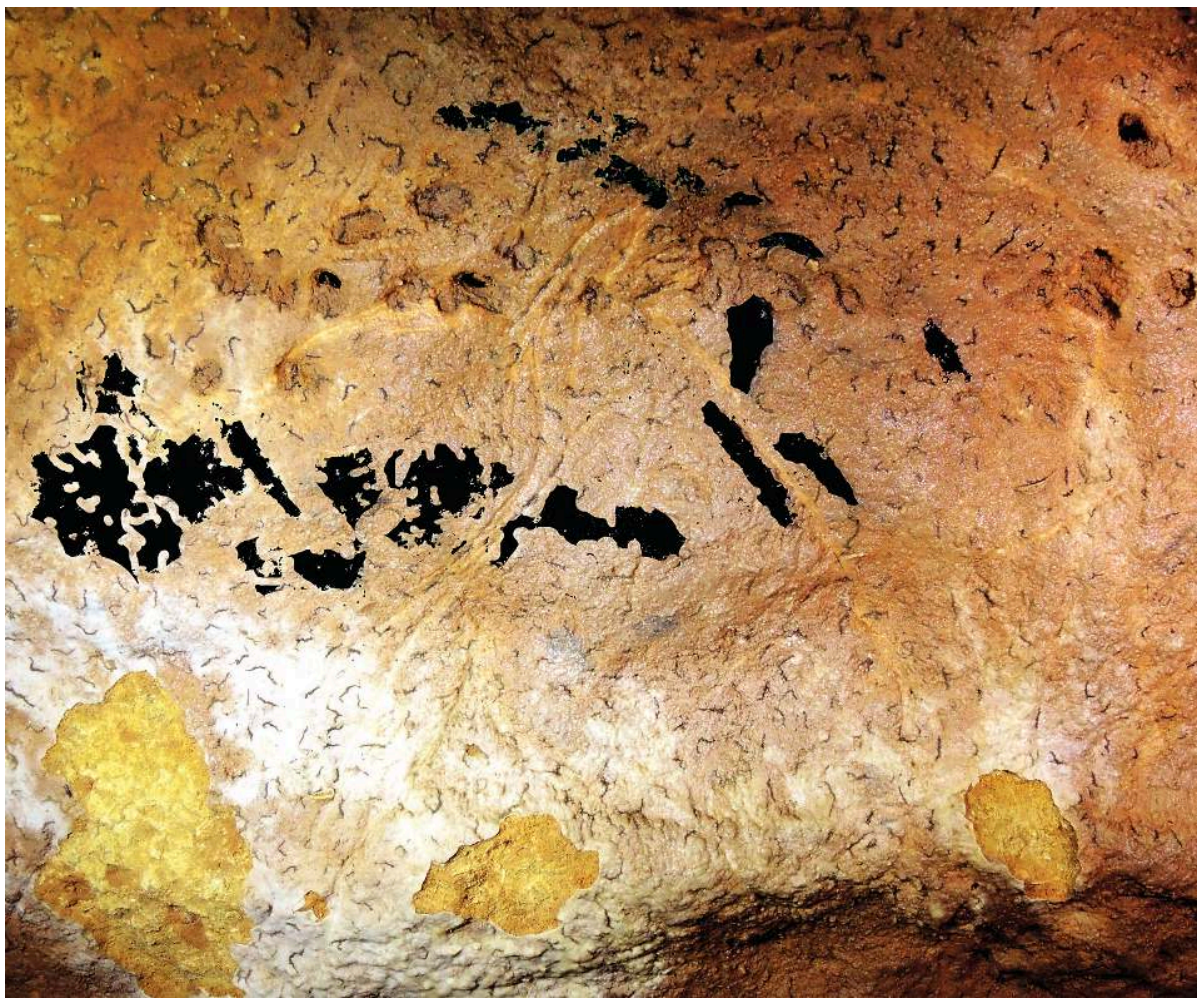

Figure 9 - Ibex 67. Improved D-Strech treatment. Picture P. Paillet, treatment E. Man-Estier.

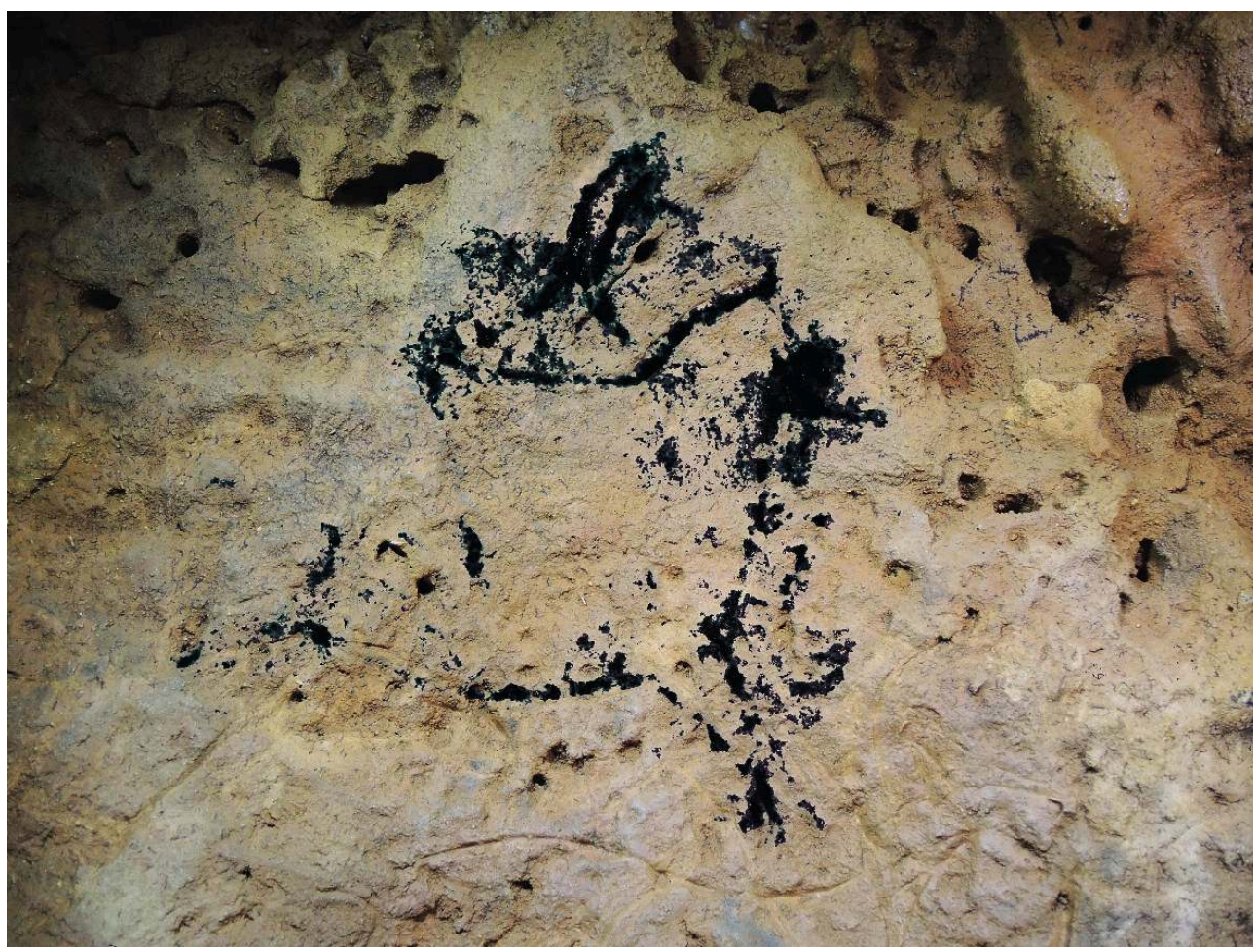




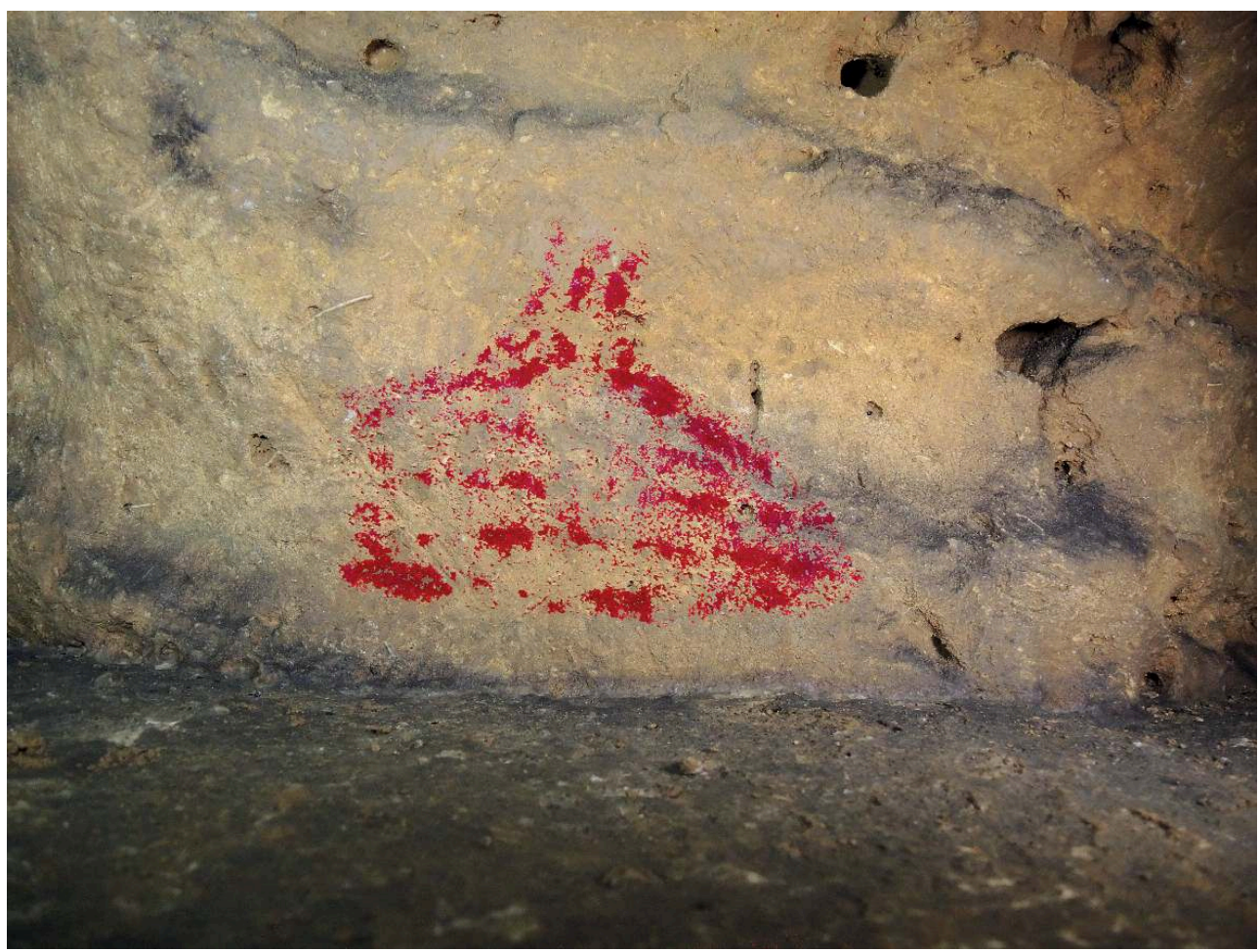

Figure 10 - Sign 46. Improved D-Strech treatment . Picture P. Paillet, treatment E. Man-Estier.

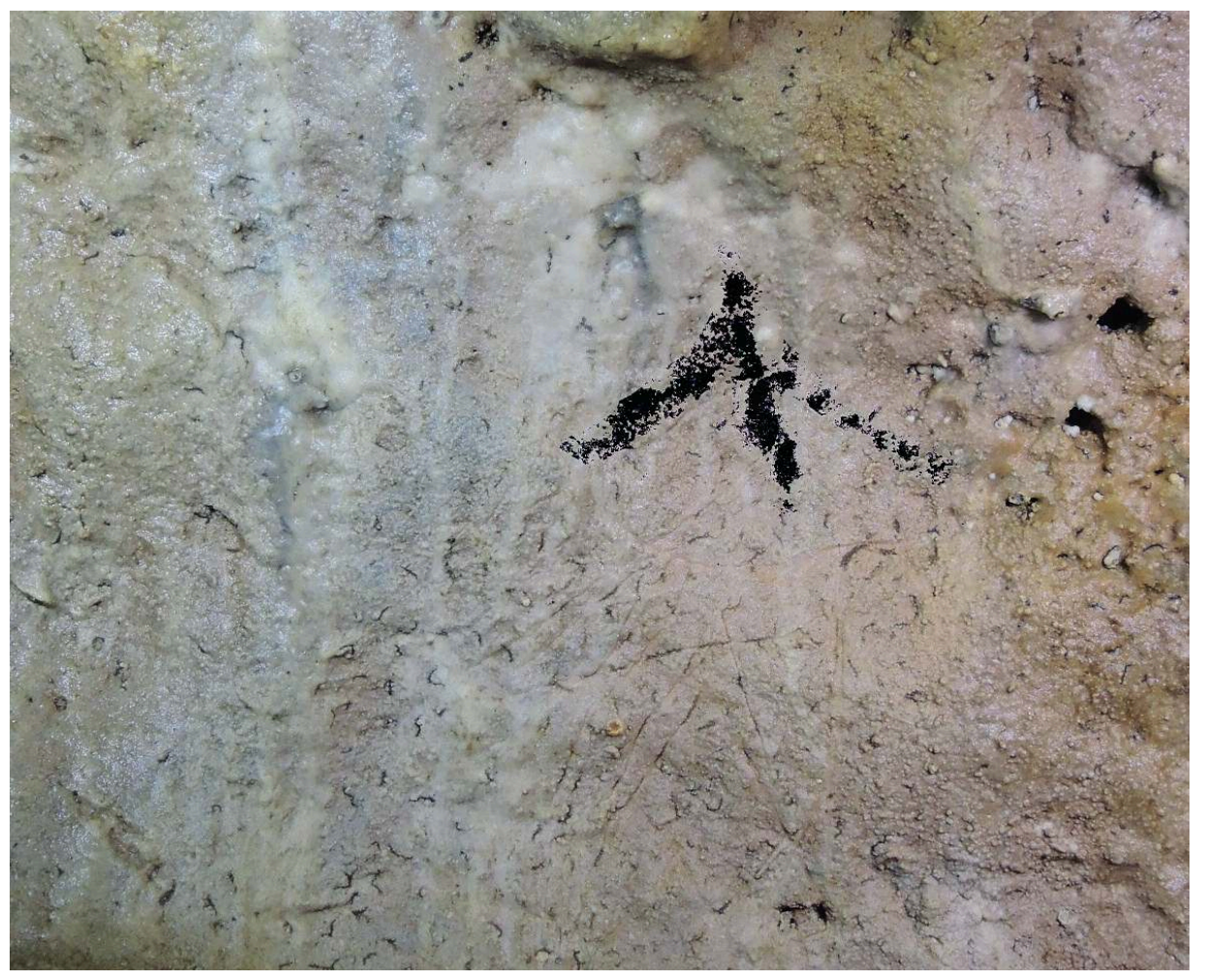


Figure 11 - Sign 121. Improved D-Strech treatment. Picture P. Paillet, treatment E. Man-Estier.

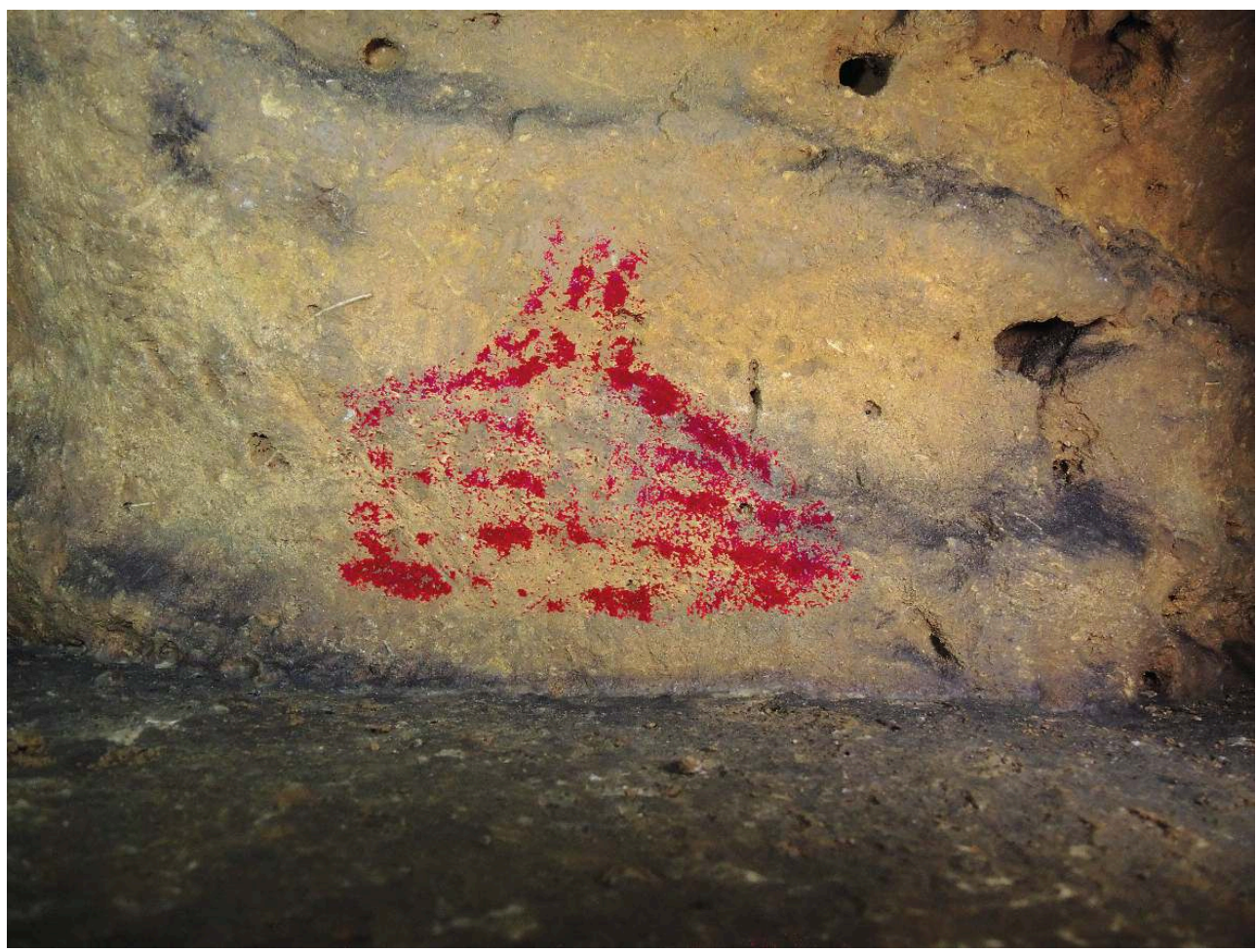

\section{An example of mixed technique: the horse 89} left wall, in the middle part of sector X. The figure is $45 \mathrm{~cm}$ long and is located about fifty centimetres above the current floor level. It was originally laying on the archaeological floor.

31 The animal is placed in a right profile and facing the back of the cave (fig. 14). It is whole and perfectly detailed. Its static position is underlined by stiff legs and a straight head and neck. The animal has a stocky morphology. The cheek and muzzle are well marked. The head is fine and completed by the nostrils, eye and ear. The mane is standing. The shoulder is marked by a thick line, perpendicular to the body.

The contour of the back is rounded, with a slightly marked saddle. The buttocks are convex and the thigh is inserted with a slight indentation that perfectly matches the anatomy of the model animal. At the front and rear, the two limbs are shown slightly crossed. The tail, thin and hanging, is also indicated.

This figure was done by a double technique of black line painting and engraving. The use of mixed techniques is known in parietal art, although it is not common. This is not a painting with some details enhanced by engraving, nor an engraved work with a few stains of colour (fig. 15). On the contrary, the animal was drawn by the two different techniques, which complement each other or are superimposed. The study of the superimpositions allows offering a chronology in three stages. We noted a first phase of fine engraving, at the neck, mane and dorsal line. It represents the general template of the figure that was positioned on the wall. This preliminary sketch was done by light engraving. The pattern was then coloured. The drawing indicates the head, the 
contours of the limbs and body and the mane. Some anatomical details, such as the ear, were then indicated. The succession of both techniques is particularly noticeable along the line of the back where there is a gap (up to $2 \mathrm{~cm}$ ) between the engraved and painted lines (fig. 15). Finally, we noted a second phase of deeper engravings. The artist drew the outline of the head by carefully applying the colour. He complemented the line of the rump and the thigh. Finally, he detailed the stomach, retracing its outline in the broad ventral strip previously done. The black modelling of the head and the mark at the shoulder do not find, up to now, a place in this graphical operating chain. A large horse, turned in the opposite direction, was engraved on the wall after the completion of the horse 89 . We can mostly note its hindquarters, the beginning of the hind limbs and the stomach line that largely obliterated the previous small horse.

From the perspective of the drawing technique, we noted that the black contour lines are of varying thickness from several millimetres to about $2 \mathrm{~cm}$. The mane, head and lower body are covered in flat colours. The mane is indicated by a very dense black colour while the modelling of the rest of the body is more diffuse. This could be due to differential preservation, but it could also be the use of two slightly different techniques, such as a more or less important dilution of the pigment. Moreover, some finer black lines, such as the ear, could have been done with a pencil or using a fine brush.

Further research and the use of experimentation may help clarify these variations.

Figure 12 - Negative hand 65. Improved D-Strech treatment . Picture P. Paillet, treatment E. ManEstier

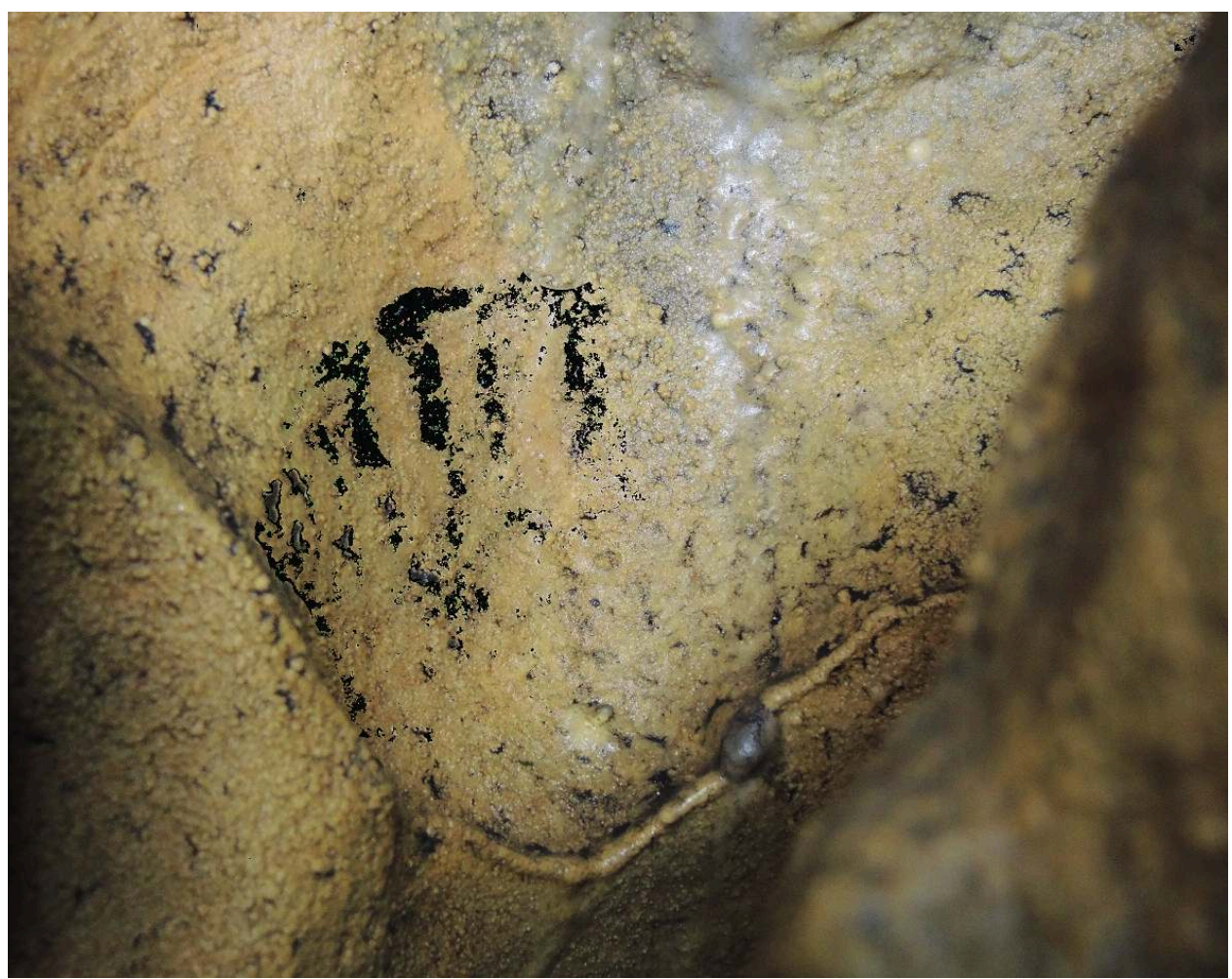


Figure 13 - Horses 109 and 110. Improved D-Strech treatment . Picture P. Paillet, treatment E. ManEstier.

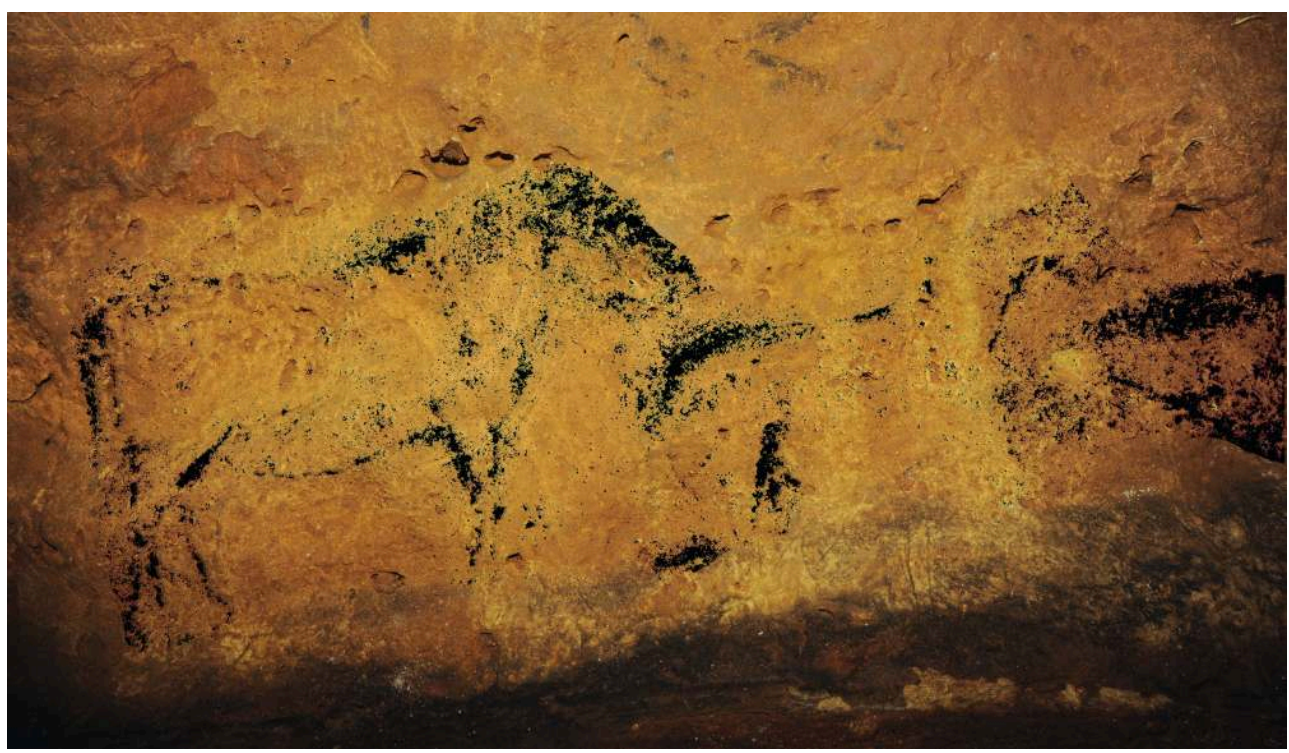

Figure 14 - Horse 89. Picture P. Paillet, tracing E. Man-Estier.

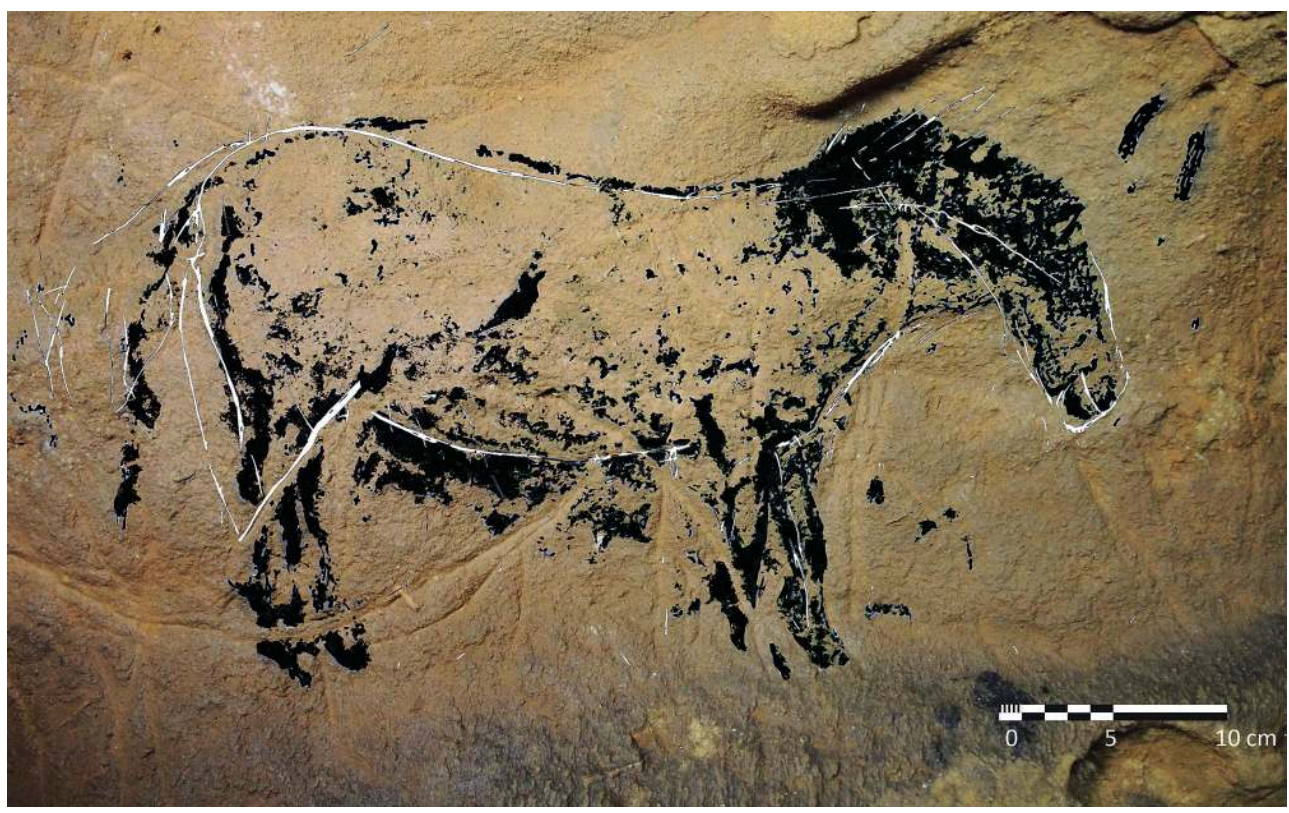




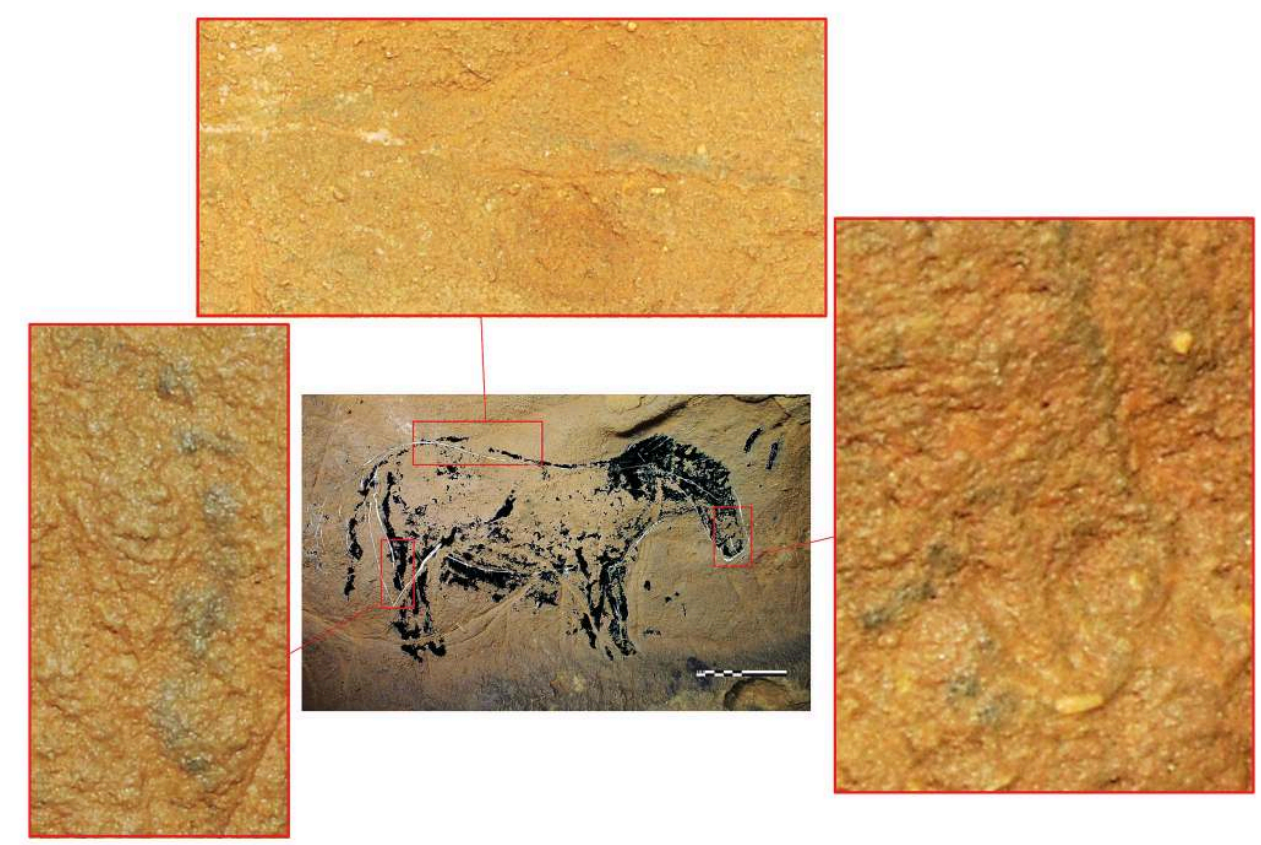

\section{Provisional conclusions}

This horse, already well known, now appears in a new light. The demonstration of the care given to the anatomical details is especially informative about the importance of these painted tracings in the eyes of the Combarelles' artists. Moreover, the existence of a true mixed technique suggests that we have one single ornamental set up, done in one time and forming a homogeneous artistic and symbolic register in the mind of prehistoric people. Then we must rethink our vision of the decoration of the cave. This is indeed in black (colour of the painting) and white (colour of the engraving) that the artists expressed themselves in Combarelles. Sometimes they added red to further enhance their work.

This note is based on an ongoing research program. It aims to recall the usefulness and desirability of new readingsreading of decorated site. Some technologies also constitute valuable support to the art analyses. This new development started with digital photography, was followed by three-dimensional recording techniques, and improved colorimetric rendering, which also allow an easier reading of what is not visible, or rather of what is hardly visible.

However, no computer will ever replace the acuity of the eye, and much less our ability to structure information and analysis. The time saved with these new tools is valuable because by simplifying work processes, they provide the researcher with more time to look at the rock wall and reveal the art works of Prehistory. 


\section{BIBLIOGRAPHY}

ARCHAMBEAU M. 1984 - Les figurations humaines pariétales périgourdines : étude d'un cas, Les Combarelles, Thèse de doctorat de l'Université d'Aix en Provence, 2 vol. , 235 p.

ARCHAMBEAU M. et C. 1986 - « Analyse typologique des figurations humaines de la grotte des Combarelles », L'Anthropologie, 90, 4, Masson, Paris, pp. 805-806,1 fig.

ARCHAMBEAU M. et C. 1991 - « Les figurations humaines pariétales de la grotte des Combarelles ", Gallia Préhistoire n³3, pp. 53-81, 43 fig.

AUJOULAT N. 1984 - «Grotte des Combarelles II. Grotte à Mentoune. Grotte de Tounialou », L'art des cavernes, Atlas des grottes ornées paléolithiques françaises, Imprimerie Nationale, Ministère de la Culture, Paris, Atlas archéologiques de la France, p. 114-118, 8 fig.

BARRIÈRE C.1980 - « La grotte des Combarelles : quelques gravures nouvelles », Travaux de l'Institut d'Art Préhistorique, XXII, Toulouse, p. 137-148

BARRIÈRE C. 1981 - « La grotte des Combarelles. Relevés des gravures pariétales de la paroi », Travaux de l'Institut d'Art Préhistorique, XXIII, Toulouse, p. 13-96.

BARRIÈRE C. 1983a - « Les peintures pariétales de Combarelles I, paroi gauche », Travaux de l'Institut d'Art Préhistorique, XXV, Toulouse.

BARRIÈRE C. 1983b - «Combarelles I, les peintures pariétales de la galerie antérieure », Travaux de l'Institut d'Art Préhistorique, XXV, Toulouse.

BARRIÈRE C. 1984 - « Grotte des Combarelles I. Grotte à Mentoune. Grotte de Tounialou. L'art des cavernes ", Atlas des grottes ornées paléolithiques françaises, Imprimerie Nationale, Ministère de la Culture, Paris, Atlas archéologiques de la France, p. 109-113, 14 fig.

BARRIÈRE C. 1985 - «Les gravures pariétales de Combarelles I, la galerie profonde », Travaux de l'Institut d'Art Préhistorique, XXVII.

BARRIÈRE C. 1987 - « Les dessins de la galerie profonde de Combarelles I », Travaux de l'Institut d'Art Préhistorique, XXIX.

BARRIÈRE C. 1992 - « Les Combarelles », La naissance de l'art en Europe, catalogue, Union Latine, Paris, p. 263-265.

BARRIÈRE C. 1997 - L'art pariétal des grottes des Combarelles, Paléo hors-série n 1, 609 p.

BRADY L.M., GUNN R.G., MCDONALDS J., VETH P. 2012, “Digital enhancement of detoriated and superimposed pigment art: methods and case studies", In McDonald J. et Veth P., dir, A companion to rock art, Blackwell, Oxford, p. 627-643.

BREUIL H. CAPITAN L. 1902 - « Gravures paléolithiques sur les parois de la grotte des Combarelles », Bulletin de la Société d'Anthropologie de Paris, volume 3, p. 527-535.

CAPITAN L., BREUIL H. 1901 - « Une nouvelle grotte avec parois gravées à l'époque paléolithique », Compte-rendu de l'Académie des Sciences, Paris.

CAPITAN L., BREUIL H. 1902a - « Figures préhistoriques de la grotte des Combarelles (Dordogne) », Compte-rendu des séances de l'Académie des Inscriptions et Belles-Lettres, 46, $\mathrm{n}^{\circ} 1$, p. 51-56. 
CAPITAN L., BREUIL H. 1902b - « La grotte des Combarelles. Les gravures sur les parois des grottes préhistoriques ", Revue de l'Ecole d'Anthropologie, 12, 1, Félix Alcan, Paris, p. 33-46, 8 fig.

CAPITAN L., BREUIL H. 1902c - « Les figures gravées à l'époque paléolithique sur les parois de la grotte des Combarelles ", Association française pour l'Avancement des Sciences, Montauban.

CAPITAN L., BREUIL H., PEYRONY D. 1924 - Les Combarelles aux Eyzies (Dordogne). Masson \& Cie Ed., Paris, Peintures et gravures murales des cavernes paléolithiques, 190 p., 127 fig.

CLEYET-MERLE J.-J. 1990 - Deux arguments décisifs, les Combarelles et Font-de-Gaume », in. Coll. Une histoire de la préhistoire en Aquitaine, Paleo, n 1, 1990, pp. 40-43.

CLEYET-MERLE J.-J., FERUGLIO V., DELLUC M. sous presse - Combarelles III - Paleo, numéro spécial Hommage à Norbert Aujoulat.

COLLECTIF (Groupe de Réflexion sur l'Art Pariétal Paléolithique), 1993, L'art pariétal paléolithique. Techniques et méthodes d'étude, Editions du CTHS, 427 p., 259 fig.

DEFRASNE C. 2014 - « Digital image enhancement for recording rupestrian engravings : applications to an alpine rockshelter ", Journal of Archeological science, vol. 50, p. 31-38.

HARMAN J. 2011 - Mode d'emploi de DStrech, disponible en ligne sur www.DStrech.com

HOLLMANN J.C., CRAUSE K. 2011 - « Digital imaging and the revelation of « hidden » rock art: Vaalekop Shelter, KwaZulu-Natal », Southern African Humanities, vol. 23, p. 55-76.

HUREL A. 2011 - L'abbé Breuil, un préhistorien dans le siècle, CNRS Edition, Paris.

LE QUELLEC, J.-L., HARMAN J., DEFRASNE C., DUQUESNOY F. 2103 - « DStrech et l'amélioration des images numériques : applications à l'archéologie des images rupestres », Les Cahiers de l'AARS, vol. 16, p. 177-198.

LE QUELLEC J.-L., DUQUESNOY F., DEFRASNE C. 2015 (manuscrit accepté) - « Digital image enhancement with DSTrech $($ : is complexity always necessary for efficiency? ", Digital applications in Archeology and cultural heritage, revue en ligne (Elsevier.com).

MAN-ESTIER E. 2009 - Les Ursidés au naturel et au figuré pendant la Préhistoire. Thèse de Doctorat de Préhistoire du Museum national d'Histoire naturelle, sous la direction de Denis vialou, 1 vol. , $801 \mathrm{p}$.

REIMER, P. J., BARD, E., BAYLISS, A., BECK, J. W., BLACKWELL, P. G., BRONK RAMSEY, C., GROOTES, P. M., GUILDERSON, T. P., HAFLIDASON, H., HAJDAS, I., HATTŽ, C., HEATON, T. J., HOFFMANN, D. L., HOGG, A. G., HUGHEN, K. A., KAISER, K. F., KROMER, B., MANNING, S. W., NIU, M., REIMER, R. W., RICHARDS, D. A., SCOTT, E. M., SOUTHON, J. R., STAFF, R. A., TURNEY, C. S. M., \& VAN DER PLICHT J. 2013 - «IntCal13 and Marine13 Radiocarbon Age Calibration Curves 0-50,000 Years cal BP », Radiocarbon, 55, vol. 4.

RIGAUD J.P. 1984 - « Grottes des Combarelles et de Font-de-Gaume », Gallia Préhistoire, Informations archéologiques : circonscription d'Aquitaine, t. 27, fasc. 2, p. 275.

RIVIÈRE E. Combarelles ", Association française pour l'avancement des Sciences, Caen.

ROUSSOT A. 1976 - «Grotte des Combarelles. Abri du Cap Blanc », Livret-Guide de l'excursion A4, Sud-Ouest (Aquitaine et Charente), IXe Congrès UISPP, p. 74-77, 3 fig.

VIALOU D.(dir.) 2004 - La Préhistoire, Histoire et dictionnaire, Bouquins, Editions Robert Laffont, Paris, $1631 \mathrm{p}$. 


\section{NOTES}

1. Upper Level 11,380 +/- 210 years BP (LY3201) and lower level 13,680 +/- 210 years BP (LY3202). Calibrated with the OxCal software and the IntCal13 curve (Reimer et al. 2013).

2. We are using in this paper interchangeably the terms for "drawing" or "painting". The method to apply the pigment seems to be line painting rather than drawing, however, as this term is used in the literature, we will also use it.

3. "The black and red drawings of Combarelles I", rock art tracings, 2014 and 2015, E. Man-Estier dir. This program fits within the Collective Research Project "Archaeology of the decorated sites of the Dordogne: conceptual framework, potential and realities', 2014-2016, coordinated by C. cretin.

\section{ABSTRACTS}

Situated in the valley of the Vézère, the cave of Combarelles I (Les Eyzies-de-Tayac, Dordogne, France) is known for its tangled engravings which are organized on both sides of the walls of a long corridor. Studies conducted until now emphasized the diversity of figurative themes expressed throughout a relative organization of the dispositive. Engravings are the main expression technique. The presence of black and red drawings or paintings is also known. Curiously, it has never been seen as an important element of the ornementation.Taking advantage of new technological medium of analysis, including colorimetric processing of the pictures, we began a new study on the painted corpus of the cavity. We are here presenting the first results of the inventory realized in 2014 and a concrete application example: a horse made of a mixed technique (drawing/engraving), in the deepest part of the cavity.

Située au cœur de la vallée de la Vézère, la grotte des Combarelles I (Les Eyzies-de-Tayac, Dordogne, France) est connue pour les gravures souvent enchevêtrées qui se déploient de part et d'autre d'un long et unique couloir. Les études conduites jusqu'à présent ont permis de souligner la diversité des thèmes figurés et l'organisation du dispositif pariétal. La principale technique d'expression est la gravure. Des représentations dessinées ou peintes en noir et en rouge sont également connues. Cependant, elles ont toujours été perçues comme des éléments secondaires et anecdotiques du décor. Mettant à profit des moyens d'analyses innovants, notamment par le biais des traitements colorimétriques de l'image, nous avons débuté une nouvelle étude du corpus peint de la cavité. Nous présentons ici les premiers résultats de nos observations, l'inventaire établi en 2014 ainsi qu'un exemple concret d'application : un cheval réalisé selon une technique mixte (gravure/peinture) dans la partie profonde de la cavité.

\section{INDEX}

Keywords: prehistoric art, Les Combarelles, Magdalenian, drawing, painting, expression techniques, digital processing

Mots-clés: art préhistorique, Les Combarelles, Magdalénien, dessin, peinture, techniques d'expression, traitements numériques de la couleur 


\section{AUTHORS}

\section{ELENA MAN-ESTIER}

Sous-direction de l'archéologie, Ministère de la culture et de la communication et UMR 5199 PACEA - elena.man-estier@culture.gouv.fr

\section{EMELINE DENEUVE}

Institut national de Recherches en archéologie préventive, Ministère de la culture et de la communication - emeline.deneuve@inrap.fr

\section{PATRICK PAILLET}

Muséum national d'Histoire naturelle - Musée de l'Homme, UMR 7194 - HNHP - paillet@mnhn.fr

\section{LUCIE LOISEAU}

Université de Bordeaux I, UMR 5199 - PACEA - loiseau.lucie40@gmail.com

\section{CATHERINE CRETIN}

Centre national de Préhistoire, Sous-direction de l'Archéologie, Ministère de la culture et de la communication et UMR 5199 - PACEA. - catherine.cretin@culture.gouv.fr 